(c) American Dairy Science Association, 2005.

\title{
Biohydrogenation of Fatty Acids and Digestibility of Fresh Alfalfa or Alfalfa Hay Plus Sucrose in Continuous Culture*
}

\author{
C. V. D. M. Ribeiro, S. K. R. Karnati, and M. L. Eastridge \\ Department of Animal Sciences, The Ohio State University, Columbus 43210
}

\begin{abstract}
The pattern of biohydrogenation of fatty acids from fresh alfalfa or alfalfa hay supplemented with 3 concentrations $(0,4$, and $8 \%)$ of sucrose was studied at a constant $\mathrm{pH}$ of 6.2. Four continuous culture fermenters were used in a $4 \times 4$ Latin square design to test the hypothesis that fresh forage would increase flow of vaccenic acid (VA) from the fermenters compared with the same forage in hay form and that this difference would be diminished by adding sucrose to the hay diet by changing the bacterial community profile. Effluent was collected from each of the 4 fermenters during the last $3 \mathrm{~d}$ of each $10-\mathrm{d}$ period. Nutrient digestibility, volatile fatty acids (VFA), and fatty acids in the effluent were measured. Flow of bacterial organic matter $(\mathrm{OM})$ and neutral and acid detergent fiber and acid detergent fiber digestibilities were higher for fresh alfalfa than alfalfa hay. True OM digestibility of alfalfa hay tended to linearly decrease with sucrose supplementation. However, microbial efficiency and flow of bacterial OM ( $\mathrm{g} / \mathrm{d}$ ) linearly increased with sucrose addition. There was no change in total VFA concentration; however, proportion of acetate linearly decreased and proportion of butyrate linearly increased with sucrose addition. Fresh alfalfa increased total biohydrogenation of fatty acids compared with than hay. Vaccenic acid flow ( $\mathrm{mg} / \mathrm{d})$ was much higher for fresh alfalfa compared with alfalfa hay (216 vs. 41 ) and VA was the predominant 18:1 isomer, followed by trans-13 18:1; however, sucrose had no effect on VA flow. The percentage of VA (of total trans18:1) was not different between fresh alfalfa and hay, whereas percentage of trans-10 18:1 was much lower for fresh alfalfa. Therefore, the ratio of VA to trans-10 18:1 was higher for fresh alfalfa. Flow of trans-12 18:1 linearly increased, whereas flows of $c i s-12$ and total cis18:1 had quadratic responses to sucrose supplementa-
\end{abstract}

Received March 4, 2005.

Accepted July 12, 2005.

Corresponding author: M. L. Eastridge; e-mail: eastridge.1@ osu.edu.

*Research was supported by State and Federal funds appropriated to the Ohio Agricultural and Development Center, The Ohio State University. tion. Total biohydrogenation and biohydrogenation of linoleic and linolenic acids linearly decreased with sucrose; however, there was no effect of sucrose on total trans fatty acid flow. Sucrose may be more detrimental to the last step of biohydrogenation of VA. The effects of sucrose on biohydrogenation and concentration of VFA may have been caused by a shift in microbial population by mechanisms that are independent of $\mathrm{pH}$.

(Key words: alfalfa, sucrose, fatty acids, biohydrogenation)

Abbreviation key: 18C = 18-carbon, $\mathrm{BH}=$ biohydrogenation, $\mathbf{C L A}=$ conjugated linoleic acid, $\mathbf{F A}=$ fatty acids, RIS = ribosomal intergenic spacer, RIS-LP = ribosomal intergenic spacer length polymorphism, UFA = unsaturated fatty acids, VA = vaccenic acid.

\section{INTRODUCTION}

Dairy products are one of the major sources of conjugated linoleic acid (CLA) in the human diet, and cis9,trans-11 octadecadienoic acid (cis-9,trans-11 18:2) contributes the greatest proportion of all CLA isomers (Parodi, 1997). Much attention has been given to CLA because of its anticarcinogenic properties (Parodi, 1997). Dietary management of dairy cows to increase CLA concentration in milk may be beneficial for human health and for the dairy industry.

Conjugated linoleic acid in milk originates from CLA produced during ruminal biohydrogenation $(\mathbf{B H})$ of linoleic acid and from desaturation of vaccenic acid (trans-11 18:1; VA) in the mammary gland. Most of the CLA in milk fat originates from VA (Kay et al., 2004); thus, many efforts have addressed ways to increase VA flow from the rumen. The factors affecting the flow of CLA isomers and trans-18:1 fatty acids (FA) to the duodenum as a result of ruminal $\mathrm{BH}$ need to be elucidated to increase the CLA concentration in milk and meat of ruminants used for human consumption.

Several researchers have reported that CLA is higher in milk from grazing animals than in that from animals fed TMR diets (Jahreis et al., 1997; Kelly et al., 1998; Dhiman et al., 1999; French et al., 2000). However, there are limited data addressing the basis for high concentration of CLA in milk from grazing cows. The 
higher concentration of CLA in milk fat from grazing animals could be a result of high concentration of octadecatrienoic acid (18:3) in fresh forage or specific plant chemicals (Lee et al., 2003), or higher concentration of soluble sugars in fresh plants (Kelly et al., 1998).

The concentrations of sugars are higher in fresh forages. Storing forages as silage or hay can decrease the concentration of FA (Boufaied et al., 2003a) and sugars in the forages (Van Soest, 1994). Traditional TMR diets have lower proportions of these nutrients compared with fresh pasture. For instance, the concentration of sugar in a TMR is about 1.5 to $3.0 \%$ of DM (Hoover and Miller-Webster, 1998), whereas the concentration of sugars in grasses averages $17 \%$ of DM, with fructosans being the major sugar, followed by sucrose, fructose, and glucose (Woolford, 1984). However, the effect of soluble sugars on $\mathrm{BH}$ has not been studied yet.

The dual-flow continuous culture system was used in the present study to assess the effect of diet on flow of $\mathrm{BH}$ intermediates without the confounding effects of variable or unpredictable passage rate, $\mathrm{pH}$, fluid dilution, meal size, and feeding frequency. Because grazing cows have higher concentration of VA in milk and almost 50\% of the sucrose is lost during hay making, we postulated that fresh forage would increase flow of VA from fermenters compared with the same forage in hay form and that sucrose addition would diminish this difference by changing the bacterial community profile.

\section{MATERIALS AND METHODS}

\section{Treatments and Experimental Design}

Fresh alfalfa samples (prebloom/early bloom) were obtained from a greenhouse at the Ohio Agricultural Research and Development Center (Wooster, $\mathrm{OH}$ ). Samples were harvested randomly and immersed immediately in liquid nitrogen using a metal grid. Samples were freeze-dried, ground at $1 \mathrm{~mm}$, and stored at $-20^{\circ} \mathrm{C}$. Purchased alfalfa hay was also ground at $1 \mathrm{~mm}$, and stored at $-20^{\circ} \mathrm{C}$.

Four continuous culture fermenters were used (Hoover et al., 1976; Hannah et al., 1986) in a $4 \times 4$ Latin square design. Each period consisted of $7 \mathrm{~d}$ for adaptation and $3 \mathrm{~d}$ for sample collection. A priori analysis of sucrose from both forages showed that $4 \%$ of supplemental sucrose added to the hay treatment would match the percentage of sucrose in the fresh alfalfa; therefore, the treatments were: 1) fresh alfalfa, 2) alfalfa hay, 3 ) alfalfa hay plus $4 \%$ sucrose (as a percentage of DM), and 4) alfalfa hay plus $8 \%$ sucrose. The percentage of nutrients from each forage source is shown in Table 1. The actual concentration of sucrose in the hay used for the project was higher than expected, resulting
Table 1. Nutrient composition of fresh alfalfa and alfalfa hay.

\begin{tabular}{|c|c|c|}
\hline Item & Fresh alfalfa & Alfalfa hay \\
\hline $\mathrm{DM}$ & $(\%$ of $\mathrm{DM})$ & 91.5 \\
\hline $\mathrm{OM}$ & 90.5 & 92.2 \\
\hline $\mathrm{CP}$ & \multirow[b]{6}{*}{$-(\%$ of FA $)$} & 20.2 \\
\hline $\mathrm{NDF}$ & & 37.9 \\
\hline $\mathrm{ADF}$ & & 26.8 \\
\hline Sucrose & & 6.78 \\
\hline Total fatty acids (FA) & & 1.07 \\
\hline Individual FA & & \\
\hline $16: 0$ & 20.8 & 30.9 \\
\hline 18:0 & 3.40 & 5.41 \\
\hline Cis-9 18:1 & 2.65 & 3.78 \\
\hline $18: 2$ & 17.0 & 19.7 \\
\hline $18: 3$ & 48.6 & 24.1 \\
\hline
\end{tabular}

in more sucrose in the alfalfa hay plus $4 \%$ sucrose treatment than in the fresh alfalfa.

\section{Continuous Culture Operation}

Ruminal inoculum was obtained from 2 ruminally cannulated Holstein cows fed a TMR diet. Within 20 min of collection, the inocula from both cows were pooled, squeezed through 2 layers of cheesecloth, and divided among the 4 fermenters. The dual-flow continuous culture system used in this study was similar to that described by Hoover et al. (1976) and modified by Hannah et al. (1986). Diets were fed (100 g of DM) continuously throughout the day using an automated augur system to provide steady state conditions. Volumes of the 4 fermenters were between 1700 and 1800 $\mathrm{mL}$. Sucrose was mixed once daily with hay before the initiation of the 24-h feeding cycle. The liquid and solid dilution rates were maintained at 10 and $5.5 \% / \mathrm{h}$, respectively, by regulation of filtrate removal rates and buffer input. Filtrate removal rate was regulated using automatic pumps. The $\mathrm{pH}$ was maintained at $6.2 \pm 0.1$ by automatic administration of $5 \mathrm{~N} \mathrm{NaOH}$ or $3 \mathrm{~N} \mathrm{HCl}$. The fermenters were continuously purged with $\mathrm{N}_{2}$ to maintain anaerobiosis, and the temperature was held at $39^{\circ} \mathrm{C}$. Temperature, acid and alkali use, filtrate flow, and $\mathrm{pH}$ were recorded and recalibrated, if needed, every $6 \mathrm{~h}$. Solid and liquid effluents were weighed once daily to determine flow rates.

\section{Sample Collection and Analysis}

One daily sample of effluent $(1 \mathrm{~L})$ was taken on $\mathrm{d} 8$, 9 , and 10 and composited by fermenter for analysis. Effluents were collected in bottles kept at $8^{\circ} \mathrm{C}$ until the end of the 24 -h period. The contents were blended using a Waring blender for $30 \mathrm{~s}$, and the effluent was strained through 2 layers of cheesecloth. Differential centrifuga- 
tion was used to first separate the feed from the bacteria $(15 \mathrm{~min}$ at $500 \times g)$ and then to separate the bacteria from the liquid supernatant $(15 \mathrm{~min}$ at $23,300 \times \mathrm{g})$. An aliquot of the effluent was acidified using $3 \mathrm{~mL}$ of $6 \mathrm{~N}$ $\mathrm{HCl}$ per $50 \mathrm{~mL}$ of sample to stop fermentation before analysis of VFA (Firkins et al., 1990). Effluent and bacteria samples were frozen, freeze-dried, and stored at $-20^{\circ} \mathrm{C}$. Both samples were analyzed for $\mathrm{N}$ by microKjeldahl (AOAC, 1990), and effluent samples were analyzed for NDF and ADF (Van Soest et al., 1991). Forage sources were also analyzed for sucrose (Hall, 2000).

The FA in the dried forages and effluent samples, stored at $-20^{\circ} \mathrm{C}$, were methylated with $0.5 \mathrm{M}$ sodium methoxide $\left(10 \mathrm{~min}\right.$ at $\left.50^{\circ} \mathrm{C}\right)$, followed by $5 \%$ methanolic $\mathrm{HCl}\left(10 \mathrm{~min}\right.$ at $\left.80^{\circ} \mathrm{C}\right)$. Nonadecanoic acid (19:0) was used as an internal standard. Retention times and response factors were determined with methyl ester standards purchased from Nu-Check Prep (Elysian, MN; cat. no. GLC-60) and Matreya, Inc. (Pleasant Gap, PA; FIM-FAME-7). The 18:1 FA that were not available commercially (trans-6/8, trans- 9 , trans- 12 , trans- 13 , trans-15, cis-12, and cis-15) were identified by order of elution (Molkentin and Precht, 1995). The FA methyl esters were separated by GLC. The column was a fused silica capillary (SP-2380, $100 \mathrm{~m} \times 0.25 \mathrm{~mm}$ i.d. $\times 0.2$ $\mu \mathrm{m}$ film thickness; Supelco Inc., Bellefonte, PA). Nitrogen was used as the carrier gas. Detector and injector temperatures were set at 250 and $220^{\circ} \mathrm{C}$, respectively, and the split ratio was set at 100:1. Oven temperature was set for $160^{\circ} \mathrm{C}$ for $10 \mathrm{~min}$, increased by $3.0^{\circ} \mathrm{C} / \mathrm{min}$ to $180^{\circ} \mathrm{C}$, held for $60 \mathrm{~min}$, increased by $5.0^{\circ} \mathrm{C} / \mathrm{min}$ to $220^{\circ} \mathrm{C}$, held for $50 \mathrm{~min}$, and decreased by $20^{\circ} \mathrm{C} / \mathrm{min}$ to $160^{\circ} \mathrm{C}$ for $1 \mathrm{~min}$. The $\mathrm{BH}$ of FA was calculated as described by Wu et al. (1991).

\section{DNA Extraction and PCR}

One sample per fermenter during each period was taken for DNA extraction and frozen at $-80^{\circ} \mathrm{C}$. Total community DNA was extracted from the effluent samples using the bead beating method ( $\mathrm{Yu}$ and Mohn, 1999) followed by purification of the DNA using a QIAamp column (Qiagen, Valencia, CA). The DNA samples were used in PCR amplification with primers S926f (5'-CTYAAAKGAATTGACGG-3') and L189r (5'-TACTGAGATGYTTMARTTC-3'). The resultant ribosomal DNA-RIS PCR products contain the complete ribosomal intergenic spacers (RIS) and parts of the flanking ribosomal DNA genes ( $600 \mathrm{bp}$ of $16 \mathrm{~S}$ rDNA and $190 \mathrm{bp}$ of 23S rDNA). The PCR conditions were as follows: initial denaturation at $94^{\circ} \mathrm{C}$ for $3 \mathrm{~min}$, annealing at $45^{\circ} \mathrm{C}$ for $1.5 \mathrm{~min}$, and extension at $72^{\circ} \mathrm{C}$ for $2.5 \mathrm{~min}$. Subsequent cycles consisted of a 1.5-min denaturation step at $94^{\circ} \mathrm{C}$, a 1.5-min annealing step at $45^{\circ} \mathrm{C}$, and a 2 -min extension step at $72^{\circ} \mathrm{C}$. After 30 cycles, there was a final 7 -min extension step at $72^{\circ} \mathrm{C}$.

\section{Phylogenetic Analysis Based on RIS-Length Polymorphism}

The PCR amplified rDNA-RIS fragments were separated on a $4 \%$ polyacrylamide (37:1) gel, and the gel was stained with GelStar nucleic acid stain (BioWhittaker, Inc., Walkersville, MD). The RIS-length polymorphism (RS-LIP) banding patterns were documented using a FluorChem Imaging System (Alpha Innotech Corporation, San Leandro, CA). The gel image was then exported into the GelCompar II analysis software in the BioNumerics package (BioSystematica, Devon, UK) for cluster analysis and dendrogram construction. The unweighted pair group method with arithmetic averages (UPGMA) method was used by the software for dendrogram construction.

\section{Statistical Analyses}

Data were analyzed by the PROC MIXED procedure of SAS (SAS Institute, 1999), according to the following model:

$$
\mathrm{Y}_{\mathrm{ijk}}=\mu+\mathrm{T}_{\mathrm{i}}+\mathrm{c}_{\mathrm{j}}+\mathrm{p}_{\mathrm{k}}+\varepsilon_{\mathrm{ijk}},
$$

where $\mathbf{Y}_{\mathbf{i j k}}=$ dependent variable for treatment $\mathrm{i}$ on fermenter $\mathrm{j}$ and period $\mathrm{k} ; \boldsymbol{\mu}=$ overall mean; $\mathbf{T}_{\mathbf{i}}=$ fixed effect of treatment $i ; \mathbf{c}_{\mathbf{j}}=$ random effect of fermenter $j$; $\mathbf{p}_{\mathbf{k}}=$ random effect of period $\mathrm{k}$; and $\varepsilon_{\mathrm{ijk}}=$ residual error associated with the ijk observation.

Preplanned contrasts were used to compare the treatment effects: 1) fresh alfalfa vs. alfalfa hay without sucrose, 2) linear effect for concentration of sucrose, and 3) quadratic effect for concentration of sucrose. Significance was declared at $P<0.05$.

\section{RESULTS}

\section{Digestibility Measures}

True OM digestibility was $14 \%$ higher $(P=0.09)$ in fresh alfalfa than alfalfa hay (Table 2 ). The digestibility of $\mathrm{N}$ tended $(P=0.11)$ to be higher and digestibilities of the NDF and ADF fractions were higher for fresh alfalfa than hay.

Addition of sucrose tended $(P=0.09)$ to decrease true $\mathrm{OM}$ digestibility. There was no effect of sucrose on NDF and ADF digestibilities. Adding 8\% sucrose decreased NDF digestibility of alfalfa hay by $14 \%$. Sucrose addition did not affect true $\mathrm{N}$ digestibility. However, there was a positive linear effect of sucrose concentration on efficiency of microbial protein synthesis and flow of 
Table 2. Nutrient digestibility in continuous culture fermenters receiving fresh alfalfa or alfalfa hay supplemented with 3 concentrations of sucrose.

\begin{tabular}{|c|c|c|c|c|c|c|c|c|}
\hline \multirow[b]{3}{*}{ Item } & \multicolumn{4}{|c|}{ Treatment } & \multirow[b]{3}{*}{$\mathrm{SE}$} & \multicolumn{3}{|c|}{ Probability of contrasts } \\
\hline & \multirow{2}{*}{$\begin{array}{l}\text { Fresh } \\
\text { alfalfa }\end{array}$} & \multicolumn{3}{|c|}{ Hay + sucrose $(\%)$} & & \multirow{2}{*}{$\begin{array}{l}\text { Fresh } \\
\text { vs. hay }\end{array}$} & \multirow[b]{2}{*}{ Linear } & \multirow[b]{2}{*}{ Quadratic } \\
\hline & & 0 & 4 & 8 & & & & \\
\hline \multicolumn{9}{|l|}{ Digestibility, \% } \\
\hline $\mathrm{OM}^{1}$ & 46.1 & 39.5 & 40.0 & 33.0 & 2.6 & 0.09 & 0.09 & 0.25 \\
\hline $\mathrm{NDF}$ & 39.1 & 31.2 & 31.9 & 26.8 & 2.6 & 0.03 & 0.18 & 0.29 \\
\hline $\mathrm{ADF}$ & 40.2 & 29.7 & 30.3 & 25.0 & 2.4 & 0.01 & 0.28 & 0.15 \\
\hline Nonbacterial N & 48.1 & 29.5 & 23.8 & 24.5 & 5.6 & 0.01 & 0.36 & 0.50 \\
\hline Bacterial OM, g/d & 14.8 & 12.3 & 12.5 & 14.4 & 0.8 & 0.02 & 0.05 & 0.25 \\
\hline Efficiency $^{2}$ & 37.6 & 36.7 & 36.3 & 56.4 & 6.2 & 0.92 & 0.04 & 0.17 \\
\hline
\end{tabular}

${ }^{1}$ True OM digestibility.

${ }^{2}$ Grams of microbial N produced per kilogram of OM truly digested.

bacterial OM in the effluent. Flow of bacterial OM was higher for fresh alfalfa; however, no difference was found on efficiency of microbial protein synthesis between alfalfa sources.

\section{VFA}

Only isobutyrate and isovalerate concentrations were affected by alfalfa source, being higher for fresh alfalfa (Table 3$)$. There was a quadratic trend $(P=0.12)$ for the concentration of total VFA to change with increasing sucrose concentration. Addition of sucrose linearly decreased molar percentage of acetate; however, no effects were observed on propionate concentration or the acetate to propionate ratio. Butyrate and valerate concentrations linearly increased with increasing sucrose addition, whereas isobutyrate and isovalerate concentrations linearly decreased as sucrose level increased.

\section{Fatty Acids and Biohydrogenation}

Flow (mg/d) of 18:0, 18:2, and 18:3 in the effluent was higher for fresh alfalfa than alfalfa hay (Table 4), but no difference was observed for cis-9 18:1. However, addition of sucrose had a quadratic effect on the flow of cis-9 18:1 without affecting the flow of the other 18carbon (18C) FA.

The $\mathrm{BH}$ of total 18C FA and the $\mathrm{BH}$ of oleic, linoleic, and linolenic acids were higher for fresh alfalfa than alfalfa hay with no supplemental sucrose. Increasing sucrose concentration linearly decreased $\mathrm{BH}$ of total 18C FA and BH of linoleic and linolenic acids, but there was no difference in the $\mathrm{BH}$ of oleic acid (Table 4).

Fresh alfalfa had a higher flow of all the intermediates of $\mathrm{BH}$ than alfalfa hay (Table 5) except for CLA and trans-10 18:1. Among the trans-18:1 FA, addition of sucrose linearly increased the flow of trans-12. Additionally, total cis-18:1 and cis-11 18:1 had a quadratic change in flow by sucrose supplementation, whereas trans-6/8 and cis-12 18:1 tended $(P<0.10)$ to decrease linearly.

The intermediates of $\mathrm{BH}$ were also reported as a percentage of the total trans- or cis-18:1 FA to compare treatment-induced changes in the pathways within each isomer group (Table 6). The percentage of trans6/8, trans-9, trans-10, trans-12, and cis-11 were lower

Table 3. Proportions of volatile fatty acids in continuous culture fermenters receiving fresh alfalfa or alfalfa hay supplemented with 3 concentrations of sucrose.

\begin{tabular}{|c|c|c|c|c|c|c|c|c|}
\hline \multirow[b]{3}{*}{ Item } & \multicolumn{4}{|c|}{ Treatment } & \multirow[b]{3}{*}{ SE } & \multicolumn{3}{|c|}{ Probability of contrasts } \\
\hline & \multirow{2}{*}{$\begin{array}{l}\text { Fresh } \\
\text { alfalfa }\end{array}$} & \multicolumn{3}{|c|}{ Hay + sucrose $(\%)$} & & \multirow{2}{*}{$\begin{array}{l}\text { Fresh vs. } \\
\text { hay }\end{array}$} & \multirow[b]{2}{*}{ Linear } & \multirow[b]{2}{*}{ Quadratic } \\
\hline & & 0 & 4 & 8 & & & & \\
\hline Total VFA, $\mathrm{m} M$ & 100.9 & 97.2 & 82.8 & 88.5 & 6.2 & 0.58 & 0.22 & 0.12 \\
\hline & & $(\mathrm{mo}$ & mo & & & & & \\
\hline Acetate & 73.6 & 74.8 & 72.8 & 71.3 & 0.9 & 0.38 & 0.02 & 0.81 \\
\hline Propionate & 14.8 & 13.5 & 14.1 & 14.9 & 0.8 & 0.28 & 0.26 & 0.96 \\
\hline Butyrate & 8.3 & 8.7 & 10.1 & 11.2 & 0.4 & 0.22 & $<0.01$ & 0.43 \\
\hline Isobutyrate & 0.58 & 0.38 & 0.25 & 0.14 & 0.04 & $<0.01$ & $<0.01$ & 0.73 \\
\hline Valerate & 1.37 & 1.61 & 1.98 & 2.20 & 0.1 & 0.20 & $<0.01$ & 0.65 \\
\hline Isovalerate & 1.31 & 1.02 & 0.75 & 0.37 & 0.10 & 0.05 & $<0.01$ & 0.60 \\
\hline Acetate:propionate & 4.99 & 5.58 & 5.20 & 4.92 & 0.33 & 0.23 & 0.18 & 0.90 \\
\hline
\end{tabular}


Table 4. Flow and biohydrogenation (BH) of 18:1, 18:2, 18:3 and BH of total 18-Carbon (18C) fatty acids (FA) in continuous culture fermenters receiving fresh alfalfa or alfalfa hay supplemented with 3 concentrations of sucrose.

\begin{tabular}{|c|c|c|c|c|c|c|c|c|}
\hline & \multicolumn{4}{|c|}{ Treatment } & \multirow[b]{3}{*}{$\mathrm{SE}$} & \multicolumn{3}{|c|}{ Probability of contrasts } \\
\hline & \multirow{2}{*}{$\begin{array}{l}\text { Fresh } \\
\text { alfalfa }\end{array}$} & \multicolumn{3}{|c|}{ Hay + sucrose $(\%)$} & & \multirow{2}{*}{$\begin{array}{l}\text { Fresh } \\
\text { vs. hay }\end{array}$} & \multirow[b]{2}{*}{ Linear } & \multirow[b]{2}{*}{ Quadratic } \\
\hline & & 0 & 4 & 8 & & & & \\
\hline \multicolumn{9}{|l|}{ Effluent } \\
\hline $18: 0$ & 920 & 315 & 247 & 256 & 106 & $<0.01$ & 0.68 & 0.75 \\
\hline cis-9 18:1 & 44.4 & 44.1 & 38.4 & 47.8 & 5.7 & 0.93 & 0.33 & 0.04 \\
\hline $18: 2$ & 192 & 141 & 129 & 163 & 26 & 0.02 & 0.22 & 0.16 \\
\hline $18: 3$ & 261 & 151 & 138 & 177 & 27 & $<0.01$ & 0.30 & 0.23 \\
\hline 18C FA & 1854 & 765 & 660 & 763 & 203 & $<0.01$ & 0.99 & 0.59 \\
\hline \multicolumn{9}{|l|}{$\mathrm{BH}^{1}$} \\
\hline Total $\mathrm{BH}^{2}$ & 66.0 & 45.0 & 41.2 & 35.9 & 2.5 & $<0.01$ & 0.01 & 0.77 \\
\hline cis-9 18:1 & 28.4 & 12.8 & 13.4 & 6.3 & 5.2 & 0.05 & 0.36 & 0.52 \\
\hline $18: 2$ & 55.3 & 47.2 & 43.8 & 38.8 & 3.3 & $<0.01$ & $<0.01$ & 0.66 \\
\hline $18: 3$ & 78.4 & 52.6 & 50.1 & 44.5 & 2.3 & $<0.01$ & 0.02 & 0.50 \\
\hline
\end{tabular}

${ }^{1}$ Percentage of fatty acids that disappeared corrected for the proportion of $18 \mathrm{C} \mathrm{FA}$ fed and in the effluent (Wu et al., 1991).

${ }^{2}$ Total 18C FA.

for fresh alfalfa than alfalfa hay. Conversely, percentages of trans-13 and cis-15 were higher for fresh alfalfa.

\section{RIS-LP Analysis}

Distinct RIS-LP banding patterns were obtained from gel electrophoresis of the PCR amplicons (Figure 1). Cluster analysis showed that the treatments tended to group together, but no distinct pattern was detected because samples taken in the same period tended to cluster together irrespective of the treatment group from which the samples were collected. However, all the sucrose treatments (hay plus 4 and $8 \%$ sucrose) grouped together, suggesting that sucrose had an effect on the bacterial population in the fermenters.
The RIS-LP followed by cluster analysis based on pairwise comparison of the banding patterns obtained from gel electrophoresis of rDNA-RIS amplicons provided a reliable and fast method for comparison of microbial community profiles in environmental samples. The banding patterns suggest that sucrose supplementation influenced bacterial community structure. Because each period was initiated by a new inoculation and the fermentations were controlled for $\mathrm{pH}$ and continuous feeding of forages, periods also had an effect on the banding patterns. However, minor alterations in bacterial species might not be easily detected because of the presence of other bacterial species in larger numbers. The use of genera- and species-specific primers

Table 5. Flow $(\mathrm{mg} / \mathrm{d})$ of the intermediates of biohydrogenation in the effluent from continuous culture fermenters receiving fresh alfalfa or alfalfa hay supplemented with 3 concentrations of sucrose.

\begin{tabular}{|c|c|c|c|c|c|c|c|c|}
\hline \multirow[b]{3}{*}{ Item } & \multicolumn{4}{|c|}{ Treatment } & \multirow[b]{3}{*}{$\mathrm{SE}$} & \multicolumn{3}{|c|}{ Probability of contrasts } \\
\hline & \multirow{2}{*}{$\begin{array}{l}\text { Fresh } \\
\text { alfalfa }\end{array}$} & \multicolumn{3}{|c|}{ Hay + sucrose $(\%)$} & & \multirow{2}{*}{$\begin{array}{l}\text { Fresh } \\
\text { vs. hay }\end{array}$} & \multirow[b]{2}{*}{ Linear } & \multirow[b]{2}{*}{ Quadratic } \\
\hline & & 0 & 4 & 8 & & & & \\
\hline CLA $^{1}$ & 15.5 & 9.7 & 5.8 & 11.0 & 2.9 & 0.12 & 0.71 & 0.16 \\
\hline Total trans-18:1 & 352.8 & 67.6 & 73.3 & 74.9 & 48.4 & $<0.01$ & 0.91 & 0.97 \\
\hline Trans-6/8 & 11.7 & 5.25 & 2.40 & 0.74 & 2.20 & 0.04 & 0.06 & 0.75 \\
\hline Trans -9 & 7.57 & 3.27 & 2.70 & 2.20 & 1.10 & $<0.01$ & 0.09 & 0.92 \\
\hline Trans-10 & 11.2 & 5.7 & 2.9 & 3.9 & 3.90 & 0.17 & 0.59 & 0.64 \\
\hline Trans-11 & 216.0 & 41.0 & 40.9 & 36.5 & 30.5 & $<0.01$ & 0.91 & 0.95 \\
\hline Trans-12 & 15.7 & 7.30 & 9.17 & 15.5 & 2.34 & $<0.01$ & $<0.01$ & 0.14 \\
\hline Trans-13 & 68.9 & 9.4 & 9.6 & 12.2 & 10.4 & $<0.01$ & 0.83 & 0.92 \\
\hline Trans-15 & 27.1 & 4.43 & 9.19 & 5.83 & 4.70 & $<0.01$ & 0.78 & 0.36 \\
\hline Total cis-18:1 & 104.8 & 70.9 & 60.9 & 72.9 & 10.23 & $<0.01$ & 0.50 & $<0.01$ \\
\hline$C i s-11$ & 19.7 & 15.6 & 12.9 & 16.3 & 1.97 & 0.01 & 0.59 & 0.03 \\
\hline Cis-12 & 10.7 & 6.85 & 5.88 & 5.49 & 1.52 & $<0.01$ & 0.07 & 0.61 \\
\hline Cis-15 & 29.9 & 4.38 & 3.72 & 3.40 & 3.07 & $<0.01$ & 0.81 & 0.96 \\
\hline
\end{tabular}

${ }^{1}$ Geometrical and positional isomers of conjugated linoleic acid (CLA). 
Table 6. Percentage of the intermediates of biohydrogenation in the effluent from continuous culture fermenters receiving fresh alfalfa or alfalfa hay supplemented with 3 concentrations of sucrose.

\begin{tabular}{|c|c|c|c|c|c|c|c|c|}
\hline \multirow[b]{3}{*}{ Item } & \multicolumn{4}{|c|}{ Treatment } & \multirow[b]{3}{*}{$\mathrm{SE}$} & \multicolumn{3}{|c|}{ Probability of contrasts } \\
\hline & \multirow{2}{*}{$\begin{array}{l}\text { Fresh } \\
\text { alfalfa }\end{array}$} & \multicolumn{3}{|c|}{ Hay + sucrose $(\%)$} & & \multirow{2}{*}{$\begin{array}{l}\text { Fresh } \\
\text { vs. hay }\end{array}$} & \multirow[b]{2}{*}{ Linear } & \multirow[b]{2}{*}{ Quadratic } \\
\hline & & 0 & 4 & 8 & & & & \\
\hline \multicolumn{9}{|l|}{ Trans-18: $1^{1}$} \\
\hline Trans-6/8 & 3.29 & 5.21 & 3.37 & 1.53 & 0.42 & $<0.01$ & $<0.01$ & 0.99 \\
\hline Trans-9 & 2.34 & 4.10 & 2.98 & 2.05 & 0.37 & 0.02 & 0.01 & 0.85 \\
\hline Trans-10 & 1.12 & 8.48 & 6.63 & 5.42 & 2.11 & 0.05 & 0.12 & 0.94 \\
\hline Trans-11 & 60.6 & 60.7 & 57.9 & 48.5 & 3.96 & 0.96 & $<0.01$ & 0.27 \\
\hline Trans-12 & 4.73 & 11.0 & 13.1 & 21.0 & 1.34 & $<0.01$ & $<0.01$ & 0.07 \\
\hline Trans-13 & 19.6 & 14.3 & 12.6 & 16.4 & 2.02 & 0.05 & 0.38 & 0.20 \\
\hline Trans-15 & 7.97 & 6.69 & 9.22 & 7.72 & 2.81 & 0.73 & 0.78 & 0.53 \\
\hline \multicolumn{9}{|l|}{ Cis-18:1 $1^{2}$} \\
\hline Cis-11 & 19.1 & 22.2 & 21.5 & 22.1 & 1.13 & $<0.01$ & 0.94 & 0.46 \\
\hline Cis-12 & 10.2 & 9.55 & 9.69 & 7.73 & 1.50 & 0.56 & 0.13 & 0.29 \\
\hline Cis-15 & 27.8 & 6.01 & 6.09 & 4.89 & 1.46 & $<0.01$ & 0.60 & 0.73 \\
\hline
\end{tabular}

${ }^{1}$ Percentage of the total trans-18:1 FA.

${ }^{2}$ Percentage of the total cis-18:1 FA.

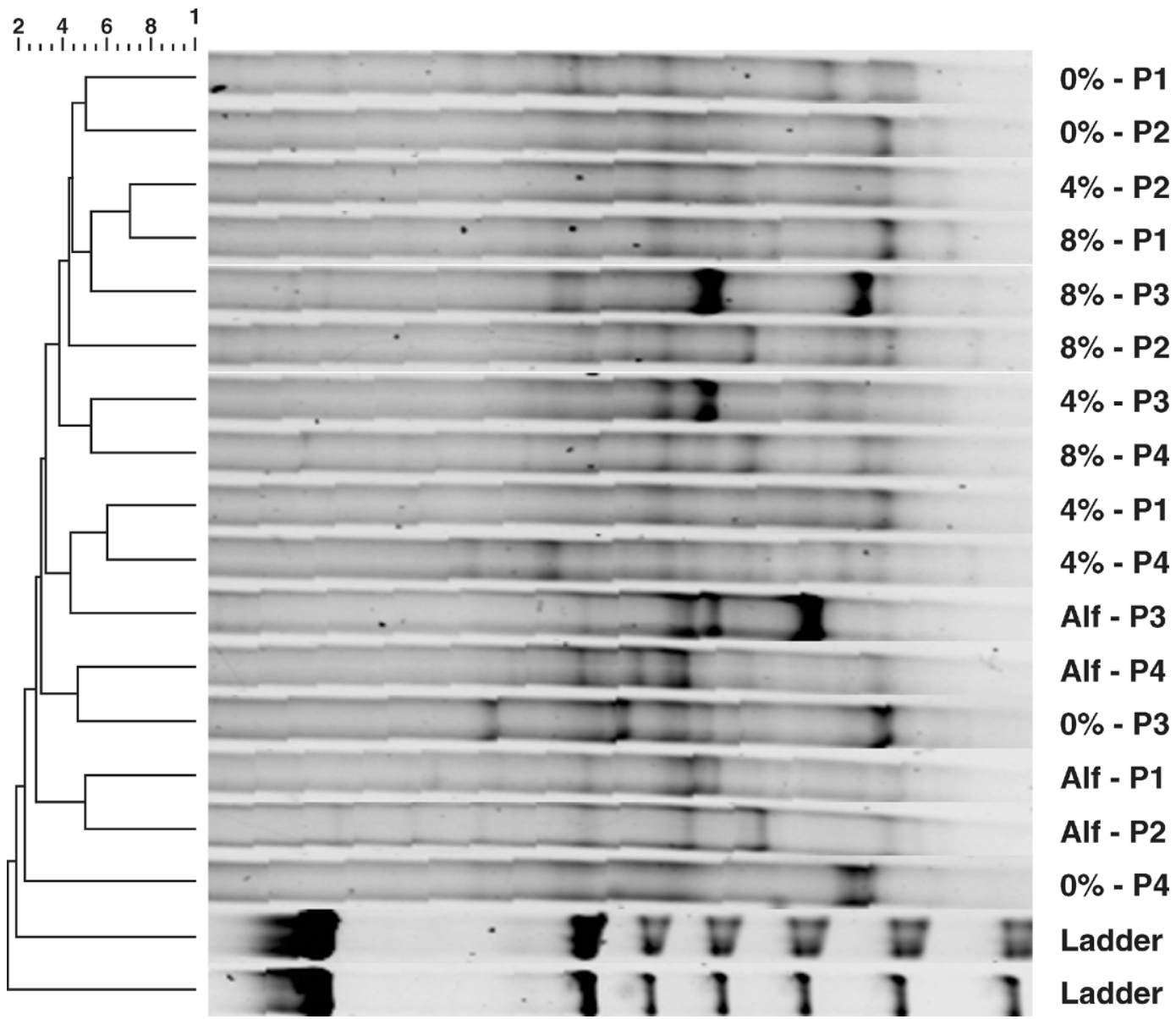

Figure 1. Comparison of bacterial community structure in fermenter samples; dendrogram shows cluster analysis performed based on sample similarities of the communities. $\mathrm{P}=$ Period 1 to $4 ; 0,4$, and $8 \%$ = percentage of sucrose supplementation on the hay treatments; and Alf $=$ fresh alfalfa. The length of scale depicts the percentage similarity between different lanes. 
would allow more specific monitoring of the minor population changes.

\section{DISCUSSION}

We reported the isolated effect of sucrose on $\mathrm{BH}$ and FA concentrations in the effluent of continuous fermenters because $\mathrm{pH}$, passage rates, and nutrient composition did not vary among the hay treatments. Fresh alfalfa was used as a positive control to show how VA and other intermediates of $\mathrm{BH}$ accumulate in the effluent and to compare the differences in $\mathrm{BH}$ attributed to forage conservation.

\section{Biohydrogenation of Fatty Acids}

The BH values observed in this experiment are similar to those reported by Qiu et al. (2004). However, other researchers have reported $\mathrm{BH}$ values for 18:2 and 18:3 higher than $80 \%$ for in vitro (Loor et al., 2003) and in vivo studies (Sackmann et al., 2003). Source of FA, level of DM intake, concentration of FA in the diet, and ruminal $\mathrm{pH}$ are some of the factors that may contribute to the differences in estimates of $\mathrm{BH}$ among experiments.

The decrease in $\mathrm{BH}$ of FA in alfalfa hay by sucrose addition may be associated with a decrease in cellulolytic microbes. Any shift in bacterial population in favor of noncellulolytic species could inhibit the $\mathrm{BH}$ of FA, because cellulolytic bacteria play a major role in ruminal BH (Harfoot and Hazlewood, 1997). Support for this hypothesis was the lower BH of total 18C FA and the numerically lower NDF and ADF digestibilities when alfalfa hay was supplemented with sucrose.

The $\mathrm{BH}$ of linoleic and linolenic acids was 14.6 and $32.9 \%$ higher, respectively, for fresh alfalfa when compared with alfalfa hay with no supplemental sucrose. Higher BH of 18:2 and 18:3 also has been reported for fresh grass compared with hay (Boufaied et al., 2003b). The composition of individual FA between grass and legumes is variable, depending on season, species, and $\mathrm{N}$ fertility (Boufaied et al., 2003a). Nutrient digestibility was higher, especially the fiber fraction, for fresh alfalfa. The lower degradability observed for hay may have physically trapped the FA within the organic matrix, decreasing release, and therefore $\mathrm{BH}$ of $18: 2$ and 18:3 (Boufaied et al., 2003b). Conversely, the flow of bacterial OM was $14 \%$ lower for hay, indicating that for a similar bacterial mass, the biohydrogenating microflora were much more active in fresh alfalfa.

The $\mathrm{BH}$ of 18:3 from fresh plants has been reported to be in the range of 80 to $90 \%$ (Loor et al., 2003; Sackmann et al., 2003). The lower BH of 18:3 for fresh alfalfa observed in the present study could be attributed to the lower digestibility of the OM fraction observed in our trial. If the plant matrix has a lower digestibility, release of FA as substrate for $\mathrm{BH}$ would be diminished.

\section{Flow of VA}

The higher CLA percentage in milk of grazing cows is largely a result of endogenous synthesis by $\Delta^{9}$-desaturase, with VA as a substrate (Kay et al., 2004). The $\mathrm{BH}$ of linolenic acid results in VA as an intermediate but not CLA (Harfoot and Hazlewood, 1997). High concentrations of VA in the duodenal digesta have been reported for ruminants consuming diets with either 18:2 or 18:3 FA as the major unsaturated FA (UFA) (Sackmann et al., 2003). Therefore, factors regulating VA synthesis and flow out of the rumen must be defined to improve our understanding of ruminal $\mathrm{BH}$.

The fresh alfalfa diet had a much higher flow of VA in the effluent than alfalfa hay with no sucrose (216 vs. $41 \mathrm{mg} / \mathrm{d}$, respectively), consistent with our hypothesis. This was most likely due to the higher percentage of 18:3 in fresh forage (Table 1). Although there was a linear decrease in $\mathrm{BH}$ of total 18C FA in the effluent as sucrose concentration increased, no differences were detected in the flow of VA and total trans FA. This observation does not support our hypothesis that the difference in VA flow between fresh alfalfa and the same forage in hay form would be diminished by adding sucrose to the hay diet. Therefore, soluble carbohydrates do not appear to be solely responsible for the higher flow of VA from the rumen of grazing cows or may not play any role.

Limitations of our study to determine the exact role of sucrose on VA accumulation in the rumen may be a result of the compartmentalization of sucrose in the fresh alfalfa samples and lack of viable protozoa in the fermenters. The location of sucrose and soluble protein in fresh alfalfa is entirely inside the plant tissue, whereas the supplemented sucrose to the hay treatments can be fermented faster; thus, the synchronism between availability of sucrose and soluble protein was not similar among treatments. Additionally, soluble sugars may be responsible for a higher number of protozoa in the rumen of cows fed fresh pasture compared with hay (Holden et al., 1994), which could not be reproduced in our fermenters. Although we are not aware of any data showing the importance of protozoa on VA flow in cows on pasture, protozoa might delay complete $\mathrm{BH}$ of UFA by engulfing bacteria and solid particles rich in trans-18:1 FA.

Supplemental sucrose decreased BH of total 18C FA and disappearance of 18:2 and 18:3, with similar flows of trans FA in the effluent of all the hay treatments. Although BH of total 18C FA was decreased by $20 \%$ 
when $8 \%$ sucrose was added, flow of VA and 18:0 decreased 13 and 19\%, respectively. Therefore, sucrose may be more detrimental to the last $\mathrm{BH}$ step (synthesis of 18:0 from trans-18:1 FA) than to the isomerization/ reduction step of 18:2 and 18:3 to trans-18:1 FA.

The concentration of VA in the effluent of continuous culture fermenters fed the fresh alfalfa was lower than reported by Loor et al. (2003). These authors reported $\sim 16 \%$ of VA (proportion of total FA) in the effluent from red clover and orchardgrass; whereas, we observed 3 to $9 \% \mathrm{VA}$ (data not shown). Our lower values were likely a result of 1) the lower OM digestibility observed in this trial, 2) type of forage and conservation method, 3) passage rate, and 4) constant $\mathrm{pH}$.

An early vegetative state of alfalfa could have increased the amount of VA formed because of its higher concentration of UFA. Because grasses have a higher proportion of 18:3 than legumes (Boufaied et al., 2003a), researchers using grasses in continuous culture reported higher concentrations of VA in the effluent (Loor et al., 2003). Moreover, alfalfa has a lower proportion of total FA and 18:3 compared with red clover (Boufaied et al., 2003a). The flow of VA in the effluent of the hay treatment was $19 \%$ of that for the fresh alfalfa. Conserved forages (hay) have a lower concentration of FA (Boufaied et al., 2003a), which decreases the amount of substrate for $\mathrm{BH}$, thus diminishing the concentration of VA in the rumen.

Higher solid and liquid passage rates may increase the flow of intermediates of BH (Qiu et al., 2004) (i.e., a higher flow rate decreases the opportunity for complete $\mathrm{BH})$. In the experiment of Loor et al. (2003), the liquid and solid passage rates were 0.18 and $0.07 / \mathrm{h}$, respectively. Those values were higher than used in this trial $(0.10$ and $0.05 / h)$. In addition, diurnal variation in ruminal $\mathrm{pH}$ of grazing animals with values falling below 6.2 (Kolver and de Veth, 2002) may inhibit BH of trans18:1 to 18:0 (Qiu et al., 2004). The result would be higher VA flow in the ruminal fluid.

\section{Intermediates of Biohydrogenation}

The flow of the intermediates of $\mathrm{BH}$ did not follow a specific pattern with sucrose addition. We cannot explain the quadratic effect of sucrose observed on the flows of total cis-18:1, cis-9, and cis-11 18:1 FA. Additionally, the cause for a linear decrease in cis-12 and increase in trans-12 18:1 FA was not apparent. Changes in the duodenal flows of trans-9, trans-12, and trans10 varied with the proportion of forage in the diet (Sackmann et al., 2003). Moreover, the initial concentration of UFA affects the rates of BH for 18:2 and 18:3 (Czerkawski, 1967). The initial concentration of UFA in the fermenters was less than $1 \mathrm{mg} / \mathrm{mL}$. Therefore, we could isolate the effect of sucrose on the parameters studied from $\mathrm{pH}$ and high initial amounts of 18:2 and 18:3.

Yu and Mohn (2001) developed a composite method for investigating bacterial community structure in an aerated lagoon. The method is based on analyses of PCR amplicons containing the RIS and its flanking partial 16S rRNA gene. Community structure similarity was determined based on RIS-LP. The 16S-23S rDNARIS region has a highly variable length and can thus be used as a marker to distinguish different bacterial species.

Using this methodology, we observed that sucrose caused a change in the bacterial community, although there also was a period effect influencing the analysis. Similar period effects have been reported previously (Noftsger et al., 2003) when bacterial community structure was analyzed in continuous culture fermenters using RIS-LP. The shift in bacterial population may have been associated with the observed effects of sucrose on some of the intermediates of $\mathrm{BH}$. Different trans-18:1 isomers (positions 6 to 16) can be formed from cis-9 18:1 (Mosley et al., 2002). However, data are not in the literature regarding how all cis and trans isomers are formed during $\mathrm{BH}$ or how the major ruminal microbial species are involved. Future research should focus on determining quantitative shifts in bacterial species by real time-PCR and correlate the results with the linear decrease in $\mathrm{BH}$. Recently, Karnati et al. (2005) excised bands from RIS-LP gels and sequenced the PCR products to determine specific changes in the ruminal bacterial community from dairy cows. Such an approach can facilitate quantification of individual bacterial genera or species as affected by different dietary treatments. We are not aware of any research showing the $\mathrm{pH}$-independent effect of sucrose on the quantitative and qualitative changes in bacterial profile using molecular techniques.

The percentage of cis-15 18:1 (of total cis-18:1 isomers; Table 6) was much higher for fresh alfalfa than for hay. Body (1976) reported that as the percentage of 18:3 increased, the proportion of cis-15 18:1 also increased in in vitro incubations. Therefore, the higher percentage of this cis-18:1 isomer reported in our trial resulted from the higher 18:3 in fresh alfalfa.

Sucrose tended ( $P=0.12$; Table 6$)$ to linearly decrease the proportion of trans-10 18:1 in the effluent. Based on flow of FA (Table 5), there was a $100 \%$ increase in the ratio of VA to trans-10 18:1 with $4 \%$ supplemental sucrose vs. hay alone. Milk fat depression has been associated with an increase in trans-10 18:1 in milk (Griinari et al., 1998). This fatty acid is probably an intermediate of $\mathrm{BH}$ of trans-10,cis-12 18:2, the CLA isomer responsible for inhibiting $\Delta^{9}$-desaturase (Park et al., 2000). The exact pathway and major player in- 
volved in the $\mathrm{BH}$ of 18:2 to trans-10 18:1 in the rumen is not known. However, manipulation of ruminal $\mathrm{BH}$ toward an increase in the ratio of VA to trans-10 18:1 would benefit herds experiencing milk fat depression.

We observed a higher ratio of VA to trans-10 in the effluent of fresh alfalfa compared with hay (19.3 vs. 7.2; Table 5). Sackmann et al. (2003) observed a linear decrease in this ratio as the proportion of forage increased in the diet of steers. These observations agree with the proposed $\mathrm{BH}$ pathway where VA is a major intermediate of $\mathrm{BH}$ of $18: 3$. Those authors also observed synthesis of cis- and trans-15 18:1 from BH of 18:3. Besides the much higher flows of those $2 \mathrm{FA}$ in the effluent of the fresh alfalfa treatment (Table 5), trans13 18:1 was the second most prevalent intermediate of $\mathrm{BH}$. We are not aware of any proposed $\mathrm{BH}$ pathway that accounts for the formation of this FA. Loor et al. (2003) have also reported trans-13 18:1 as the second major 18:1 FA in the effluent of continuous culture fermenters. There is still a need to understand how the major factors (diet composition, ruminal parameters, and population of microorganisms) of ruminal $\mathrm{BH}$ are correlated.

\section{Digestibility}

Although there is a large variation in NDF digestibilities reported in the literature, the NDF digestibilities observed in this trial for hay and fresh alfalfa are in agreement with a previous study (Bach et al., 1999). The variation observed in NDF digestibility among experiments using continuous culture fermenters may be caused by differences in forage sources and maturity, $\mathrm{pH}$, inoculum, and liquid and solid passage rates (Qiu et al., 2004).

True OM digestibilities for hay and hay plus $4 \%$ sucrose were very similar, whereas the value for hay plus $8 \%$ sucrose was $16 \%$ lower than hay alone. The true OM digestibilities are in agreement with previous published data (Griswold et al., 1996, 2003; Bach et al., 1999; Qiu et al., 2004). Sucrose addition has been reported to reduce the rates of fiber fermentation in situ (Huhtanen and Khalili, 1992). Addition of $8 \%$ sucrose negatively affected true OM digestibility of hay, most likely reflecting the numerical decrease in nonbacterial N, NDF, and $\mathrm{ADF}$ digestibilities by a $\mathrm{pH}$-independent mechanism. A decrease in NDF digestibility by addition of soluble sugars with $\mathrm{pH}$ higher than 6.2 has been reported previously (Piwonka and Firkins, 1996).

Some cellulolytic bacteria are able to use soluble sugars as well as fiber (Huhtanen and Khalili, 1992), changing their metabolism according to substrate availability (Russell and Baldwin, 1978). We postulate that sucrose decreased nutrient digestibility by shifting ei- ther bacterial ecology or metabolism, or both. Russell and Baldwin (1978) reported alterations in bacterial growth rates with a combination of different carbohydrates. Therefore, sucrose addition may have favored growth of bacteria species that have faster growth rates when fermenting this sugar. Furthermore, sucrose may decrease fiber digestibility by decreasing fibrolytic enzyme activity (Huhtanen and Khalili, 1992; Piwonka and Firkins, 1993), possibly explaining the numerical decrease in fiber digestibility in this trial.

Bacterial OM flow increased $14 \%$ and microbial efficiency increased $35 \%$ from 0 to $8 \%$ sucrose. A similar increase in efficiency has been reported in Holstein heifers supplemented with dextrose (Piwonka et al., 1994). We reported higher values for microbial efficiency (Table 2), likely caused by the lower values observed for true OM digestibilities. Meng et al. (1999) observed a higher microbial efficiency for nonfibrous carbohydrate sources compared with fibrous sources in continuous culture fermenters at higher dilution rates $(0.15$ and $0.20 / \mathrm{h}$ ). However, these observations were different at lower dilution rates. Supplemental sucrose provided a more readily available energy source, contributing to higher efficiency and bacterial OM flow.

Nutrients in fresh alfalfa were more digestible than those in hay. Harvest of alfalfa to represent the selection of the immature plants during grazing conditions resulted in a lower percentage of NDF compared with hay. Higher nutrient digestibilities for fresh alfalfa resulted in higher bacterial OM flow. Sucrose content of fresh alfalfa was 2 percentage units higher than for alfalfa hay (Table 1). A possible synchronism between $\mathrm{N}$ and sucrose release from the plant matrix and fermentation may have contributed to the almost 2-fold increase in true $\mathrm{N}$ digestibility for fresh alfalfa. Moreover, fresh forages have higher concentrations of other rapidly fermented sugars that are lost during wilting and higher concentration of more digestible protein (Van Soest, 1994).

\section{VFA}

Total VFA concentrations observed in this experiment were similar to previous reports that used continuous culture fermenters (Bach et al., 1999) and grazing animals (Reis and Combs, 2000). The reason for the quadratic effect of sucrose addition on VFA concentration is not certain; such a quadratic response was not observed elsewhere in this trial, except for a quadratic trend observed for the percentage of CLA in the effluent.

Degradation of fiber in the rumen is associated with a higher molar proportion of acetate to propionate (Van Soest, 1994). Changes in fermentation patterns likely reflect shifts in bacterial population that respond to 
changes in fermentable substrates. The decrease in acetate concentration as sucrose concentration increased is consistent with the numerically lower NDF digestibility observed for the highest concentration of sucrose. The change in molar proportion of butyrate was the most pronounced of all, with a $22 \%$ increase in concentration at the highest concentration of sucrose. Crawford et al. (1980) also reported reciprocal changes in acetate and butyrate concentrations by varying liquid dilution rate. Addition of sucrose also linearly increased the concentration of valerate, whereas isobutyrate and isovalerate concentrations were decreased. When taken together, these observations support our hypothesis that addition of sucrose caused a shift in the bacterial population.

The molar proportion of butyrate has been reported to increase with addition of soluble sugars (Piwonka and Firkins, 1996) and concentrate feeds (Reis and Combs, 2000). Soluble sugars are the main carbohydrate substrate for holotrichs (Van Soest, 1994). However, continuous culture fermenters are associated with a decrease in protozoal population and even greater reductions in protozoa numbers were observed with solid dilution rates higher than $0.04 / \mathrm{h}$ (Hoover et al., 1976). Therefore, the higher butyrate concentration observed in this experiment was not likely caused by an increase in protozoal cells. The higher butyrate concentration could be attributed to a change in fermentation pathways to accommodate the higher flux of hydrogen from the rapidly fermented sugar source (Piwonka and Firkins, 1996). Moreover, the higher molar proportion of butyric acid could be attributed to its synthesis from lactate by Megasphaera elsdenii (Klieve et al., 2003).

No difference was observed for the major VFA between fresh alfalfa and hay; however, isobutyrate and isovalerate were higher for fresh alfalfa compared with hay, whereas these branched-chain VFA linearly decreased with sucrose addition. Valerate was not different between fresh and hay but linearly increased with sucrose. The branched-chain VFA resulted from fermentation of branched-chain amino acids. The change in branched-chain VFA likely is related to the difference in $\mathrm{N}$ digestibility observed in this trial.

\section{CONCLUSIONS}

Our data reject the hypothesis that increasing sucrose supplementation to alfalfa hay would increase flow of VA from the fermenters. However, addition of sucrose changed microbial populations; as concentration of sucrose increased, BH of total 18C FA decreased by a $\mathrm{pH}$-independent process. Synthesis of VA and trans FA were not changed by sucrose addition. The final step of $\mathrm{BH}$, reduction of trans-18:1 to 18:0, may be more sensitive to the suppressing effect of sucrose supplementation.

The VA was the major octadecenoic acid in the effluent of all treatments, followed by trans-13 18:1. Adding sucrose to hay shifted the intermediates of $\mathrm{BH}$ independently of $\mathrm{pH}$ and concentrations of UFA.

Fresh alfalfa had a higher digestibility of NDF and $\mathrm{ADF}$ and tended to have a higher true OM digestibility than alfalfa hay. Addition of sucrose tended to decrease true OM digestibility of hay and improve efficiency of microbial protein synthesis. Sucrose addition decreased acetate and increased butyrate concentrations. The $\mathrm{BH}$ of total 18C FA for fresh alfalfa was higher than for alfalfa hay. Future research needs to link the sucroseinduced changes in $\mathrm{BH}$ with changes in metabolites and a shift in microbial species in the rumen.

\section{ACKNOWLEDGMENTS}

The authors would like to thank Susan Noftsger and John Sylvester for helping with the fermenters. Our gratitude is extended to Donald Palmquist, Chris Reynolds, and Jeffrey Firkins for their suggestions.

\section{REFERENCES}

AOAC. 1990. Official Methods of Analysis. Vol. I. 15th ed. Association of Official Analytical Chemists, Arlington, VA.

Bach, A., I. K. Yoon, M. D. Stern, H. G. Jung, and H. Chester-Jones. 1999. Effects of type of carbohydrate supplementation to lush pasture on microbial fermentation in continuous culture. J. Dairy Sci. 82:153-160.

Body, D. R. 1976. The occurrence of cis-octadec-15-enoic acid as a major biohydrogenation product from methyl linolenate in bovine rumen liquor. Biochem. J. 157:741-744.

Boufaied, H., P. Y. Chouinard, G. F. Tremblay, H. V. Petit, R. Michaud, and G. Belanger. 2003a. Fatty acids in forages. I. Factors affecting concentrations. Can. J. Anim. Sci. 83:501-511.

Boufaied, H., P. Y. Chouinard, G. F. Tremblay, H. V. Petit, R. Michaud, and G. Belanger. 2003b. Fatty acids in forages. II. In vitro ruminal biohydrogenation of linolenic and linoleic acids from timothy. Can. J. Anim. Sci. 83:513-522.

Crawford, R. J., Jr., W. H. Hoover, and P. H. Knowlton. 1980. Effects of solids and liquid flows on fermentation in continuous cultures. I. Dry matter and fiber digestion, VFA production and protozoa numbers. J. Anim. Sci. 51:975-985.

Czerkawski, J. W. 1967. Incubation inside the bovine rumen. Br. J. Nutr. 21:865-878.

Dhiman, T. R., G. R. Anand, L. D. Satter, and M. W. Pariza. 1999 Conjugated linoleic acid content of milk from cows fed different diets. J. Dairy Sci. 82:2146-2156.

Firkins, J. L., W. P. Weiss, M. L. Eastridge, and B. L. Hull. 1990. Effects of feeding fungal culture extract and animal-vegetable fat on degradation of hemicellulose and on ruminal bacterial growth in heifers. J. Dairy Sci. 73:1812-1822.

French, P., C. Stanton, F. Lawless, E. G. O’Riordan, F. J. Monahan, P. J. Caffrey, and A. P. Moloney. 2000. Fatty acid composition, including conjugated linoleic acid, of intramuscular fat from steers offered grazed grass, grass silage, or concentrate-based diets. J. Anim. Sci. 78:2849-2855.

Griinari, J. M., D. A. Dwyer, M. A. McGuire, D. E. Bauman, D. L. Palmquist, and K. V. V. Nurmela. 1998. Trans-octadecenoic acids and milk fat depression in lactating dairy cows. J. Dairy Sci. $81: 1251-1261$. 
Griswold, K. E., G. A. Apgar, J. Bouton, and J. L. Firkins. 2003. Effects of urea infusion and ruminal degradable protein concentration on microbial growth, digestibility, and fermentation in continuous culture. J. Anim. Sci. 81:329-336.

Griswold, K. E., W. H. Hoover, T. K. Miller, and W. V. Thayne. 1996. Effect of form of nitrogen on growth of ruminal microbes in continuous culture. J. Anim. Sci. 74:483-491.

Hall, M. B. 2000. Subject: Neutral detergent-soluble carbohydrates. Nutritional relevance and analysis. Online. Available http:// www.animal.ufl.edu/nutrition.html. Accessed Dec. 5, 2002.

Hannah, S. M., M. D. Stern, and F. R. Ehle. 1986. Evaluation of a dual flow continuous culture system for estimating bacterial fermentation in vivo of mixed diets containing various soybean products. Anim. Feed Sci. Technol. 16:51-62.

Harfoot, C. G., and G. P. Hazlewood. 1997. Lipid metabolism in the rumen. Pages 382-426 in The Rumen Microbial Ecosystem. 2nd ed. P. N. Hobson, ed. Elsevier, London, UK.

Holden, L. A., L. D. Muller, G. A. Varga, and P. J. Hillard. 1994. Ruminal digestion and duodenal nutrient flows in dairy cows consuming grass as pasture, hay, or silage. J. Dairy Sci. 77:3034-3042.

Hoover, W. H., B. A. Crooker, and C. J. Sniffen. 1976. Effects of differential solid-liquid removal rates on protozoa numbers in continuous cultures of rumen contents. J. Anim. Sci. 43:528-534.

Hoover, W. H., and T. K. Miller-Webster. 1998. Role of sugars and starch in ruminal fermentation. Pages 1-16 in Proc. Tri-State Dairy Nutrition Conf., Fort Wayne, IN. The Ohio State University, Columbus.

Huhtanen, P., and H. Khalili. 1992. The effect of sucrose supplements on particle-associated carboxymethylcellulase (EC 3.2.1.4) and xylanase (EC 3.2.1.8) activities in cattle given grass-silage-based diet. Br. J. Nutr. 67:245-255.

Jahreis, G., J. Fritsche, and H. Steinhart. 1997. Conjugated linoleic acid in milk fat: High variation depending on production system. Nutr. Res. 17:1479-1484.

Karnati, S. K., J. T. Sylvester, Z. Yu, N. R. St-Pierre, and J. L. Firkins. 2005. Detecting changes in bacterial and protozoal populations in ruminal fluid and omasal samples from cows fed supplemental methionine. Page 13 in Proc. Conf. Gastrointestinal Function, Chicago, IL. M. A. Cotta, ed. USDA-ARS, Peoria, IL.

Kay, J. K., T. R. Mackle, M. J. Auldist, N. A. Thomson, and D. E. Bauman. 2004. Endogenous synthesis of cis-9, trans-11 conjugated linoleic acid in dairy cows fed fresh pasture. J. Dairy Sci. 87:369-378.

Kelly, M. L., E. S. Kolver, D. E. Bauman, M. E. Van Amburgh, and L. D. Muller. 1998. Effect of intake of pasture on concentrations of conjugated linoleic acid in milk of lactating cows. J. Dairy Sci. $81: 1630-1636$

Klieve, A. V., D. Hennessy, D. Ouwerkerk, R. J. Forster, R. I. Mackie, and G. T. Attwood. 2003. Establishing populations of Megasphaera elsdenii YE 34 and Butyrivibrio fibrisolvens YE 44 in the rumen of cattle fed high grain diets. J. Appl. Microbiol. 95:621-630.

Kolver, E. S., and M. J. de Veth. 2002. Prediction of ruminal pH from pasture-based diets. J. Dairy Sci. 85:1255-1266.

Lee, M. R., L. J. Harris, R. J. Dewhurst, R. J. Merry, and N. D. Scollan. 2003. The effect of clover silages on long chain fatty acid rumen transformation and digestion in beef steers. Anim. Sci. 76:491-501.

Loor, J. J., W. H. Hoover, T. K. Miller-Webster, J. H. Herbein, and C. E. Polan. 2003. Biohydrogenation of unsaturated fatty acids in continuous culture fermenters during digestion of orchardgrass or red clover with three levels of ground corn supplementation. J. Anim. Sci. 81:1611-1627.
Meng, Q, M. S. Kerley, P. A. Ludden, and R. L. Belyea. 1999. Fermentation substrate and dilution rate interact to affect microbial growth and efficiency. J. Anim. Sci. 77:206-214.

Molkentin, J., and D. Precht. 1995. Optimized analysis of transoctadecenoic acids in edible fats. Chromatographia 41:267-272.

Mosley, E. E., G. L. Powell, M. B. Riley, and T. C. Jenkins. 2002. Microbial biohydrogenation of oleic acid to trans isomers in vitro. J. Lipid Res. 43:290-296.

Noftsger, S. M., N. R. St-Pierre, S. K. R. Karnati, and J. L. Firkins. 2003. Effects of 2-hydroxy-4-(methylthio) butanoic acid (HMB) on microbial growth in continuous culture. J. Dairy Sci. 86:2629-2636.

Park, Y., J. M. Storkson, J. M. Ntambi, M. E. Cook, C. J. Sih, and M. W. Pariza. 2000. Inhibition of hepatic stearoyl-CoA desaturase activity by trans-10,cis-12 conjugated linoleic acid and its derivatives. Biochim. Biophys. Acta 1486:285-292.

Parodi, P. W. 1997. Cows' milk fat components as potential anticarcinogenic agents. J. Nutr. 127:1055-1060.

Piwonka, E. J., and J. L. Firkins. 1993. Effect of glucose on fiber digestion and particle-associated carboxymethylcellulase activity in vitro. J. Dairy Sci. 76:129-139.

Piwonka, E. J., and J. L. Firkins. 1996. Effect of glucose fermentation on fiber digestion by ruminal microorganisms in vitro. J. Dairy Sci. 79:2196-2206.

Piwonka, E. J., J. L. Firkins, and B. L. Hull. 1994. Digestion in the rumen and total tract of forage-based diets with starch or dextrose supplements fed to Holstein heifers. J. Dairy Sci. 77:1570-1579.

Qiu, X., M. L. Eastridge, K. E. Griswold, and J. L. Firkins. 2004. Effects of substrate, passage rate, and $\mathrm{pH}$ in continuous culture on flows of conjugated linoleic acid and trans C18:1. J. Dairy Sci. 87:3473-3479.

Reis, R. B., and D. K. Combs. 2000. Effects of increasing levels of grain supplementation on rumen environment and lactation performance of dairy cows grazing grass-legume pasture. J. Dairy Sci. 83:2888-2898.

Russell, J. B., and R. L. Baldwin. 1978. Substrate preferences in rumen bacteria: Evidence of catabolite regulatory mechanisms. Appl. Environ. Microbiol. 36:319-329.

Sackmann, J. R., S. K. Duckett, M. H. Gillis, C. E. Realini, A. H. Parks, and R. B. Eggelston. 2003. Effects of forage and sunflower oil levels on ruminal biohydrogenation of fatty acids and conjugated linoleic acid formation in beef steers fed finishing diets. J. Anim. Sci. 81:3174-3181.

SAS Institute. 1999. SAS/STAT User's Guide. Version 8 ed. SAS Institute, Inc., Cary, NC

Van Soest, P. J. 1994. Nutritional ecology of the ruminant. Cornell University Press, Ithaca, NY.

Van Soest, P. J., J. B. Robertson, and B. A. Lewis. 1991. Methods for dietary fiber, neutral detergent fiber, and nonstarch polysaccharides in relation to animal nutrition. J. Dairy Sci. 74:35833597.

Woolford, M. K. 1984. The Silage Fermentation. Vol. 14. Microbiology Series. A. I. Laskin, and R. I. Mateles, ed. Marcel Dekker, Inc., New York, NY.

Wu, Z., O. A. Ohajuruka, and D. L. Palmquist. 1991. Ruminal synthesis, biohydrogenation, and digestibility of fatty acids by dairy cows. J. Dairy Sci. 74:3025-3034.

Yu, Z., and W. M. Mohn. 1999. Killing two birds with one stone: Simultaneous DNA and RNA extractions from activated sludge biomass. Can. J. Microbiol. 45:269-272.

Yu, Z., and W. W. Mohn. 2001. Bacterial diversity and community structure in an aerated lagoon revealed by ribosomal intergenic spacer analyses and 16S ribosomal DNA sequencing. Appl. Environ. Microbiol. 67:1565-1574. 